\title{
Hypoglycaemia induced by antibodies to insulin receptor following a bone marrow transplantation in an immunodeficient child
}

\author{
N. Rochet ${ }^{1}$, S. Blanche ${ }^{2}$, J.C.Carel ${ }^{2}$, A. Fischer ${ }^{2}$, F. L. Deist ${ }^{2}$, C. Griscelli ${ }^{2}$, E. Van Obberghen ${ }^{1}$ \\ and Y. Le Marchand-Brustel ${ }^{1}$ \\ ${ }^{1}$ INSERM U145, Faculté de Médecine, Nice, and ${ }^{2}$ INSERM U132, Département de Pédiatrie, Hôpital Necker, Paris, France
}

\begin{abstract}
Summary. Severe hypoglycaemia developed seven months after a bone marrow transplantation in a child with severe combined immunodeficiency. His serum exerted potent insulin-like activity: (a) it stimulated insulin receptor autophosphorylation and kinase activity in cell-free systems, this effect being additive to insulin; (b) it increased glucose transport in isolated soleus muscle. These insulin-like effects were due to immunoglobulins against the insulin receptor. Indeed, the patient serum immunoprecipitated human or murine insulin receptors from different tissues and inhibited insulin binding to
\end{abstract}

receptor on human IM-9 lymphocytes. After corticoids and immunosuppressive therapy by azathioprine, the patient hypoglycaemic episodes disappeared, and concomitantly, the antibodies to insulin receptor were no longer detected, as judged by both immunoprecipitation of insulin receptor and stimulation of glucose transport.

Key words: Insulin receptor, tyrosine kinase, insulin-like activity, antibodies to insulin receptor.
Autoantibodies to insulin receptor have first been described in rare disorders with, in most cases, a clinical history of extreme insulin resistance [1]. More recently, the presence of such autoantibodies has been found in patients suffering from hypoglycaemia, in a context of complex autoimmune syndrome [2-4] or Hodgkin's disease $[5,6]$. We herein describe the case report of a child who presented severe hypoglycaemia, due to antibodies to insulin receptor and whose clinical features differed from previously reported cases. Furthermore, this antibody presents biological characteristics which so far have not been described for other human autoantibodies to insulin receptor.

\section{Subject and methods}

\section{Materials}

Radioactive substances were purchased from the Radiochemical Centre, Amersham, UK. All other agents were of the best grade commercially available and were from Sigma, St. Louis, Mo, USA. All reagents for SDS-gel electrophoresis were from Bio-Rad Laboratories, Richmond, Calif., USA.

\section{Subject}

A seven month old child (P.S.) had severe combined immunodeficiency characterised by the absence of $T$ lymphocytes with normal B lymphocyte counts [7]. He received a T-cell depleted HLA partially incompatible bone marrow graft from his mother without prior condi- tioning. T-cell depletion was performed using the CAMPATH I monoclonal antibody [8] and human complement. HLA incompatibility concerned one full HLA haplotype [9]. No graft versus host disease (GVHD) prophylaxis was given. There has been no detectable complication of the bone marrow graft and five months after the transplantation, his $\mathrm{T}$ and B cell immunodeficiency was corrected. During the 7 th month post transplant, a severe hypoglycaemic state developed, with attacks leading to convulsions or coma. There was no ketosis, insulin levels were low and serum cortisol level was normal. There were no antibodies against insulin or pancreatic islet cells. Simultaneously, other autoimmune manifestations occurred including haemolytic anemia, thrombocytopenia, and neutropenia. Furthermore, liver enzymes were increased without manifestations of hepatocellular failure. A liver biopsy showed an histologic aspect of active chronic hepatitis. No other serum antibodies were detected including antibodies to endocrine glands. The prevention of hypoglycaemia necessitated regular carbohydrate feeding. Corticotherapy (prednisone, $2 \mathrm{mg} / \mathrm{kg} / 24 \mathrm{~h}$ ) was begun to control the autoimmune manifestations. Azathioprine $(2 \mathrm{mg} / \mathrm{kg} / 24 \mathrm{~h}$ ) was added in a second phase because of the chronic hepatitis. Following treatment, the hypoglycaemic episodes disappeared progressively in 15 days.

\section{Insulin binding inhibition assays}

Binding of ${ }^{125} \mathrm{I}$-insulin was measured on human IM-9 lymphocytes or on fibroblasts transfected with human insulin receptor cDNA as previously described [10]. Membranes were prepared from rat liver [11] or human placenta [10] and insulin binding measured as described [11]. Insulin receptors were solubilised from the same sources and insulin binding measured as follows: $10 \mu 1$ of receptor preparations were incubated in $150 \mu \mathrm{l}$ Hepes $(50 \mathrm{mmol} / \mathrm{l}, \mathrm{pH} \mathrm{7.4}), \mathrm{NaCl}(150 \mathrm{mmol} / \mathrm{l})$ buffer in presence of P.S. or control serum at various dilutions. Following this incubation $\left(3 \mathrm{~h}, 15^{\circ} \mathrm{C}\right),{ }^{125} \mathrm{I}$-insulin binding was measured after $2 \mathrm{~h}$ at $15^{\circ} \mathrm{C}$ as described [12]. 


\section{Insulin receptor immunoprecipitation}

Human insulin receptors from HIRc cells (rat embryo fibroblasts transfected with human insulin receptor cDNA [13]) and receptors from rat liver or mouse skeletal muscle were partially purified by Triton X-100 solubilisation and chromatography on wheat germ agglutinin agarose (WGA) [14]. The insulin receptor $\beta$-subunit was labelled by autophosphorylation as follows: WGA eluates were incubated for $120 \mathrm{~min}$ at $20^{\circ} \mathrm{C}$ with insulin $(1 \mu \mathrm{mol} / \mathrm{l})$. The phosphorylation reaction was initiated by addition of $\left[\gamma_{-}{ }^{32}-\mathrm{P}\right]$ ATP (15 $\mu \mathrm{mol} / \mathrm{l}), \mathrm{MnCl}_{2}(4 \mathrm{mmol} / \mathrm{l}), \mathrm{MgCl}_{2}(8 \mathrm{mmol} / 1)$ [15]. After $15 \mathrm{~min}$ at $20^{\circ} \mathrm{C}$, the reaction was stopped by adding ice-cold stopping solution (NaF $100 \mathrm{mmol} / \mathrm{l}$, EDTA $20 \mathrm{mmol} / 1$, final concentrations) and phosphoproteins were immunoprecipitated by P.S. serum $(1 / 20$ to $1 / 100$ dilution) or control serum (1/20 dilution) for $12 \mathrm{~h}$ at $4^{\circ} \mathrm{C}$ followed by addition of protein $\mathrm{A}$. The pellets containing the immunoadsorbed proteins were washed, and subsequently analysed by sodium dodecyl sulfate/polyacrylamide gel electrophoresis (SDS/PAGE) according to Laemmli [16].

\section{Insulin receptor autophosphorylation and kinase activity}

The ability of P.S. serum to stimulate insulin receptor autophosphorylation was studied by incubation of receptor preparations with serum in absence or presence of insulin for $2 \mathrm{~h}$ at $22^{\circ} \mathrm{C}$. Phosphorylation was then carried out as described above and samples were directly analysed by SDS/PAGE.

The effect of serum on insulin receptor kinase activity was measured as follows: WGA preparations were pre-incubated with serum and/or insulin for $2 \mathrm{~h}$ at $15^{\circ} \mathrm{C}$. The substrate (poly[glutamatetyrosine, 4-1], $0.25 \mathrm{mg} / \mathrm{ml}$ ) was added for an additional $30 \mathrm{~min}$. Phosphorylation was then performed as previously described [17].

\section{Preparation of purified immunoglobulins}

Immunoglobulins were purified as follows: serum was incubated for $4 \mathrm{~h}$ at $4^{\circ} \mathrm{C}$ with protein A sepharose. Following washing with $100 \mathrm{vol}$ of Hepes $(30 \mathrm{mmol} / 1, \mathrm{pH} 7.4), 30 \mathrm{mmol} / 1 \mathrm{NaCl}$ buffer, immunoglobulins fractions were eluted with citrate buffer $(0.1 \mathrm{~mol} / 1, \mathrm{pH} 3.5)$ and rapidly neutralised with Tris buffer $(1 \mathrm{~mol} / 1, \mathrm{pH} 8)$. Fractions containing proteins were dialysed, concentrated by ultrafilttation and then used for receptor immunoprecipitation and autophosphorylation as described above.

\section{Bioassay of insulin-like activity}

Insulin-like activity of the patient's serum was tested by its ability to stimulate glucose transport in mouse skeletal muscle as follows. Soleus muscles were isolated and pre-incubated for $90 \mathrm{~min}$ at $37^{\circ} \mathrm{C}$ with a normal serum or the patient's serum as previously described [18]. Thereafter, muscles were washed twice for $5 \mathrm{~min}$ at $20^{\circ} \mathrm{C}$ to remove all serum factors not tightly bound. Muscles were then incubated for $15 \mathrm{~min}$ at $37^{\circ} \mathrm{C}$, in presence or absence of insulin, with 1 - $\left[{ }^{14} \mathrm{C}\right.$-2-deoxyglucose $(0.5 \mathrm{mmol} / 1,0.5 \mu \mathrm{Ci} / \mathrm{ml})$, deoxyglucose uptake being an index of glucose transport and phosphorylation. Muscles were washed and radioactivity counted [18].

\section{Statistical analysis}

Statistical significance in incubated muscles experiments was assessed using Student's t test for unpaired comparisons [19].

\section{Results}

\section{Evidence for the presence of antibodies to insulin receptor}

The clinical picture of hypoglycaemic episodes without hyperinsulinaemia and with ketone levels below the limit of detection in a context of autoimmune disease suggested that the patient serum could contain antibodies to insulin receptor. We first tested P. S. serum for its ability to immunoprecipitate human insulin receptors, whose $\beta$-subunit was labelled by autophosphorylation with $\left[\gamma^{32} \mathrm{P}\right]$ ATP. As shown in Figure 1, P.S. serum was able to precipitate a significant amount of labelled receptors in a dose-dependent manner. At a 1/50 dilution, it was as potent as serum from patient B7 (a gift of Dr P Gorden, NIH, Bethesda, Md, USA) used at a $1 / 150$ dilution. This $B 7$-patient suffered from a severe insulin resistance due to antibodies against the insulin receptor [2]. P.S. antibody was able to recognise insulin receptors not only from human sources (Fig.1), but also from mouse skeletal muscle and from rat liver (data not shown). This antibody was specific for insulin receptor, since it did not recognise the EGF receptor also present in rat liver preparations (data not shown).

Serum from P.S. was then examined for its ability to interfere with insulin binding to receptor. No inhibition was observed with solubilised receptors or plasma membranes. In contrast, the patient's serum was able to compete with ${ }^{125} \mathrm{I}$-labelled insulin binding to human IM-9 lymphocytes, half maximal inhibition being obtained at a $1 / 50$ dilution (Table 1). Similar inhibition of insulin binding was observed with cells transfected with

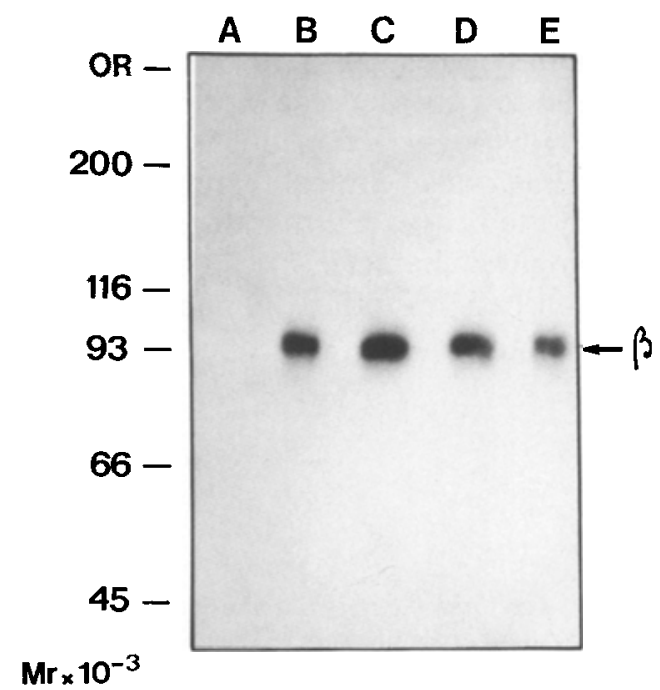

Fig. 1. Immunoprecipitation of insulin receptors by P.S. serum. Partially purified human insulin receptors, prepared from HIRc cells as described in the methods, were labelled with $\left[\gamma_{-}{ }^{32} \mathrm{P}\right] \mathrm{ATP}$. The phosphorylation reaction was stopped with $\mathrm{NaF}$, EDTA. Serum was added for $12 \mathrm{~h}$ at $4^{\circ} \mathrm{C}$ as follows: Control serum 1/20, lane $\mathrm{A}$; Patient B7 1/150, lane B; Patient P.S. 1/20, lane C, 1/50, lane D, 1/100, lane $E$. After addition of protein $A$, the immunoprecipitates were analysed by sodium dodecyl sulfate polyacrylamide gel electrophoresis (SDS/PAGE) under reducing conditions. The insulin receptor $\beta$-subunit is indicated 
Table 1. Effect of P.S. serum on ${ }^{125}$ I-insulin binding to IM-9 lymphocytes

\begin{tabular}{ll}
\hline P.S. Serum dilution & $\begin{array}{l}125 \text { I-insulin binding } \\
\text { (percent of control serum) }\end{array}$ \\
\hline $1 / 750$ & 93.3 \\
$1 / 500$ & 92.6 \\
$1 / 300$ & 85.4 \\
$1 / 200$ & 82.0 \\
$1 / 100$ & 66.4 \\
$1 / 50$ & 47.5 \\
$1 / 20$ & 22.3 \\
\hline
\end{tabular}

Human IM-9 lymphocytes $\left(10^{6}\right.$ cells $\left./ \mathrm{ml}\right)$ were pre-incubated for $120 \mathrm{~min}$ at $30^{\circ} \mathrm{C}$ with P.S. or control serum at indicated dilution. Thereafter, ${ }^{125} \mathrm{I}$-labelled insulin was added for $180 \mathrm{~min}$ at $15^{\circ} \mathrm{C}$. At the end of incubation, cells were centrifuged, washed and the radioactivity bound to cells counted. Results of binding obtained with P.S. serum are expressed as a percentage of the binding observed with control serum at the same dilution

human insulin receptor cDNA (data not shown). Taken together, our results indicate that P.S. serum contained antibodies which were able to immunoprecipitate insulin receptors and to inhibit insulin binding in intact cells.

\section{Insulinomimetic effect of the antibodies to receptor}

To explain the hypoglycaemia of P.S., we next searched for insulin-like activities of these antibodies. We first studied the ability of this serum to stimulate glucose uptake in skeletal muscle, an important tissue for glucose utilisation. As shown in Figure 2, patient serum markedly stimulated deoxyglucose uptake in basal condition (no insulin). This insulinomimetic effect was very pronounced since, at a 1/50 dilution, its effect was similar to that obtained with a submaximal insulin concentration. This stimulatory action could very likely not be accounted for by insulin or serum factors other than antibodies to insulin receptor, since it prevailed after two washes of muscles and measurement of deoxyglucose uptake being performed in serum-free medium. The effects of serum and insulin were additive, but only when the hormone was used at a submaximal concentration.

The insulin receptor $\beta$-subunit is a tyrosine kinase whose autophosphorylation is stimulated by the hormone. A large body of evidence clearly indicates that this receptor enzymatic activity plays an essential role in insulin's biological actions [20, 21]. It was thus of interest to investigate whether the patient serum was able to activate the insulin receptor kinase on solubilised receptors. As shown in Figure 3, left panel, P.S. serum obtained during the hypoglycaemic period increased ${ }^{32} \mathrm{P}$ incorporation in the $95 \mathrm{~K}$ insulin receptor $\beta$-subunit (lane C) compared to normal serum (lane A) or mother

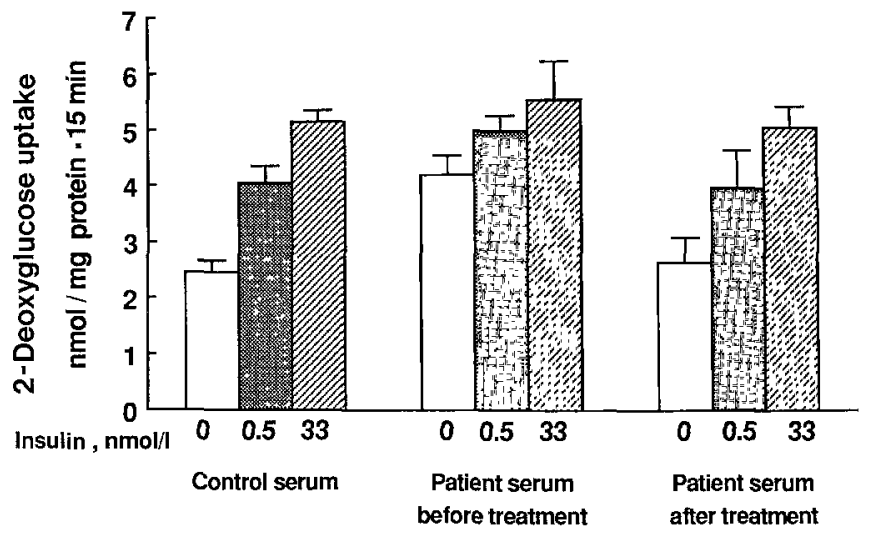

Fig. 2. Insulinomimetic effect of P.S. serum on glucose uptake in mouse skeletal muscle. Soleus muscles were pre-incubated with P.S. or control serum obtained before and after treatment (dilution 1/20) for $90 \mathrm{~min}$ at $37^{\circ} \mathrm{C}$. After 2 washes $(5 \mathrm{~min}$ each), they were incubated for $15 \mathrm{~min}$ at $37^{\circ} \mathrm{C}$ without or with insulin, and $1-\left[{ }^{14} \mathrm{C}\right] 2$-deoxyglucose $(0.5 \mathrm{mmol} / 1,0.1 \mu \mathrm{Ci} / \mathrm{ml})$. Muscles were then treated as described in methods. Each value is the mean \pm SEM of $4-8$ individual muscles. $\square=$ No insulin; $=$ Insulin, $0.5 \mathrm{nmol} / 1 ;$ 圂=Insulin, $33 \mathrm{nmol} / 1$
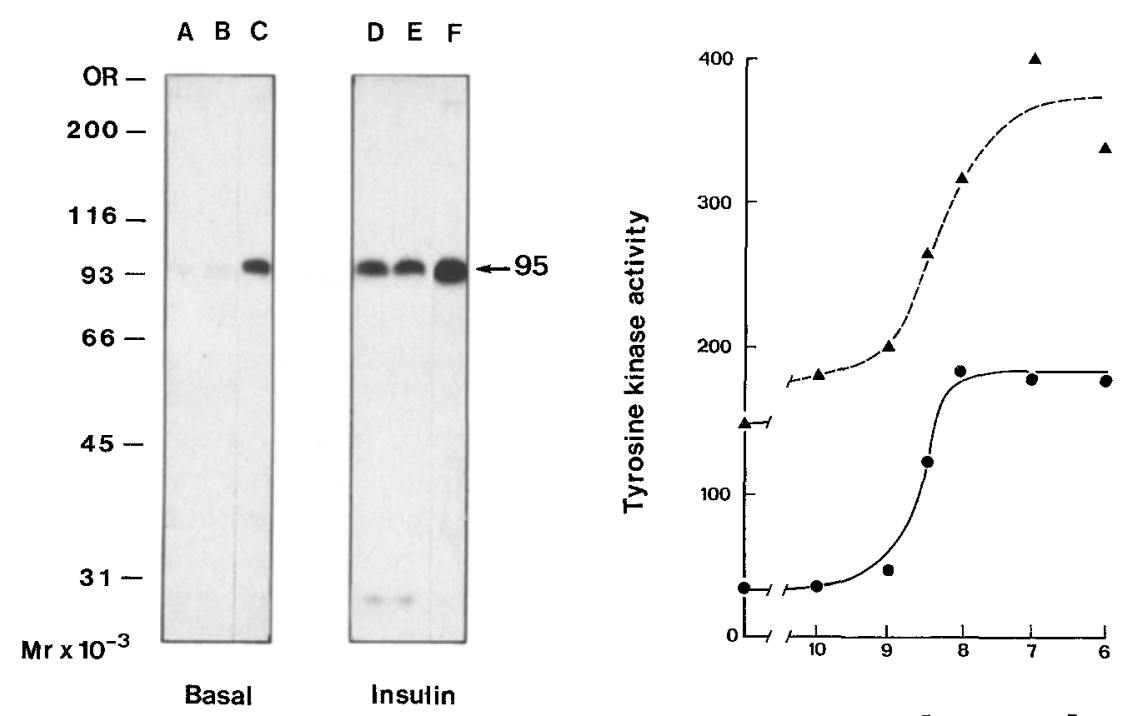

Insulin [- Log mol/l]
Fig. 3. Activation of the insulin receptor kinase by P.S. serum. Left panel: Receptor autophosphorylation: partially purified human insulin receptors, prepared from HIRc cells as described in the methods, were pre-incubated for $120 \mathrm{~min}$ with serum from the control (lanes A, D), P. S.' mother (lanes B, E) or P.S. (lanes C, F) at $1 / 20$ dilution, in absence (basal) or presence of insulin $(1 \mu \mathrm{mol} / 1)$. Then autophosphorylation was carried out as described in methods, and the samples were analysed by SDS/PAGE. The $95 \mathrm{~K}$ band corresponds to the insulin receptor $\beta$-subunit. Right panel: The effect of patient ( or control (-) serum on insulin receptor tyrosine kinase activity towards the poly(glutamatetyrosine) was measured at different insulin concentrations and expressed in nmoles of ${ }^{32} \mathrm{P}$ incorporated per $30 \mathrm{~min}$ as described in methods 

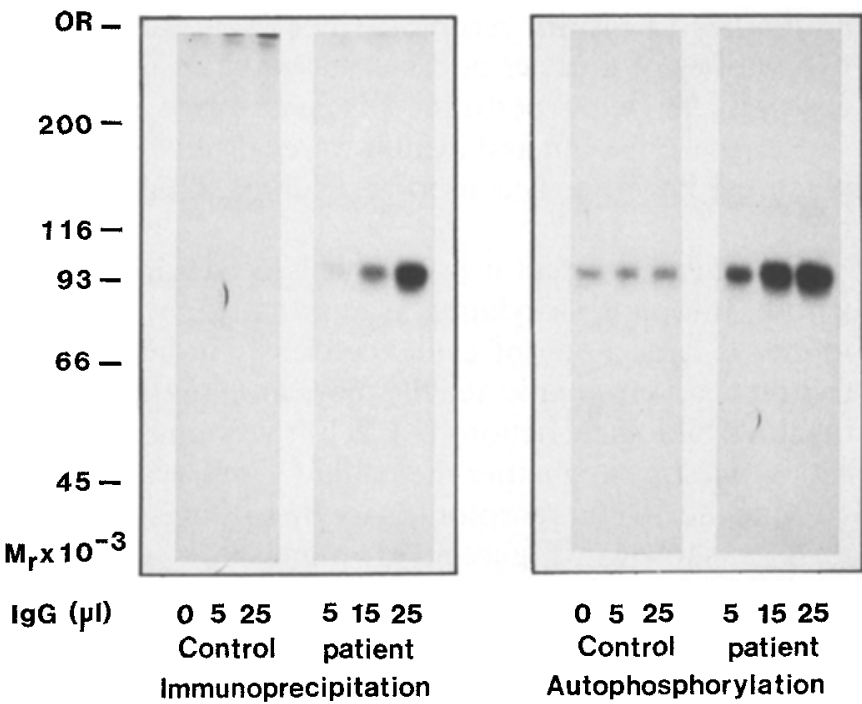

Fig.4. Immunoprecipitation of insulin receptors and activation of receptor autophosphorylation by P.S. immunoglobulins. Immunoglobulins were purified from P.S. or control serum by protein A chromatography as described in methods. Immunoprecipitation of labelled insulin receptors (left panel) and receptor autophosphorylation (right panel) were performed as described in legends to Figures 1 and $3 . \operatorname{IgG}$ concentration was $6 \mu \mathrm{g} / \mu \mathrm{l}$

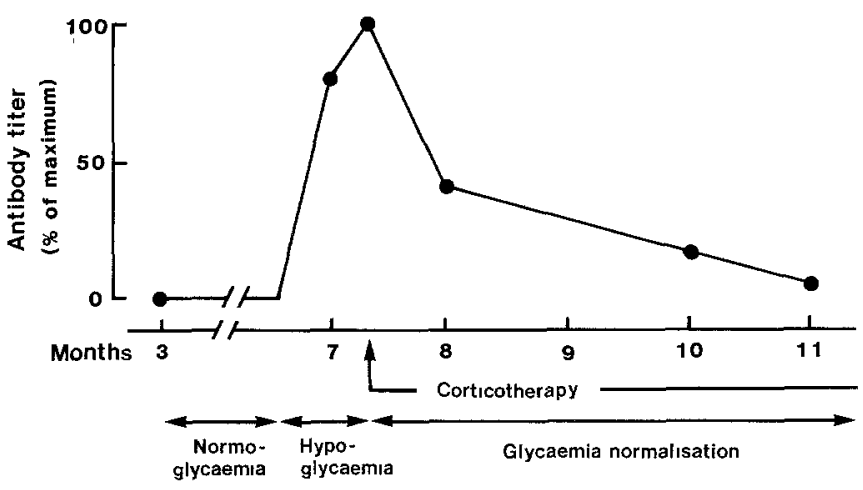

Fig.5. Parallel evolution of antibodies to insulin receptor and glycaemic state following the bone marrow transplantation to P.S. The titer of the antibodies against insulin receptor was measured by its ability to immunoprecipitate insulin receptor. Results are expressed as a percentage of the maximal titer observed just before corticotherapy

serum, the bone marrow donor (lane B). This antibody was as potent as a maximally effective insulin concentration $(1 \mu \mathrm{mol} / \mathrm{l})$ in stimulating insulin receptor autophosphorylation (lanes D, E). Further, the effects of antibodies and insulin were additive (lane F). Similar results were obtained when the tyrosine kinase activity towards a synthetic copolymer of glutamate-tyrosine was measured (Fig. 3, right panel). P.S. serum alone was as potent as insulin in stimulating this activity, and the effects of both agents were additive.

To substantiate the nature of the serum factor which was responsible for the observed effects, immunoglobulins fractions were purified from control serum and P.S. serum by protein A chromatography. The fraction eluted from the patient serum was able to immunopre- cipitate phosphorylated insulin receptor, while the control immunoglobulins were without effect (Fig.4, left panel). More important, this fraction was also able to stimulate insulin receptor autophosphorylation in a dose-dependent fashion (Fig. 4, right panel). These results indicate that the serum effects could be assigned to immunoglobulins of the $\mathrm{IgG}$ class.

\section{Antibodies to the insulin receptor are responsible for the patient's hypoglycaemia}

Analysis of serum samples obtained at different periods of the illness substantiated the role of the antibodies in the pathogenesis of the hypoglycaemic syndrome. First, a serum obtained from P.S. three months after the transplantation, before any sign of glycaemic disorder, fail to induce immunoprecipitation or autophosphorylation of insulin receptors. More important, these activities disappeared after three weeks of prednisone therapy and the biological evolution of P. S. serum coincided with a marked clinical improvement of his glycaemic control (Fig. 5). Moreover, the causal relationship between hypoglycaemia and antibodies was further established by the evolution of the insulin-like effect of patient serum on glucose uptake in muscle. As shown in Figure 2, P.S. serum obtained three weeks after the beginning of corticotherapy was no longer able to stimulate 2-deoxyglucose uptake in muscle.

\section{Discussion}

We describe here the appearance of antibodies to insulin receptor in a young immunodeficient child, who had received a bone marrow transplantation. The key interest in this case report comes from the fact that several biological and clinical features differed markedly from those described previously. The vast majority of autoantibodies to insulin receptor have been found in patients with insulin resistance [2]. In contrast to those patients, P.S. developed profound hypoglycaemia explained by the very potent insulin-like activity of his antibodies. Indeed, at a 1/20 dilution, his serum was as potent as insulin in activating insulin receptor autophosphorylation and tyrosine kinase activity towards a synthetic substrate in a cell-free system (Fig.3). Further, addition of insulin was still able to increase the level of insulin receptor kinase activity already obtained with P.S. serum alone. Such additive effect of insulin and antibodies on insulin receptor had not been reported with autoantibodies from patients [6] but has been reported only in the case of a polyclonal antibody raised in rabbit against a purified insulin receptor preparation [10]. Our observation, on solubilised receptors, of an antibody with additive effect to maximally effective insulin concentrations without inhibition of insulin binding, suggests that this antibody binds to the receptor at a 
locus distinct from the hormone binding site. Its interaction with receptor is such that it leads to a powerful activation of the receptor tyrosine kinase. The decrease in insulin binding found solely in intact cells would indicate that an active cellular process is involved in this loss of binding.

When the effect of P.S. serum was tested in skeletal muscle, an important organ for insulin action and glucose utilisation, a marked insulin-like activity was observed on glucose uptake and phosphorylation. At maximally effective concentrations, the effects of insulin and antibodies were not additive on glucose uptake, suggesting that the limiting step was glucose transport and not the stimulation of kinase activity. A similar observation has been reported for insulin-induced effects in cells expressing a 100-1000 increase in receptor number. Thus, only the sensitivity to insulin was increased, while the maximal biological response to the hormone was unchanged [22, 23].

The striking parallelism between the evolution of the presence of antibodies to insulin receptor and the glycaemic episodes demonstrates the pathogenetic role of these antibodies in the clinical syndrome. Indeed, when hypoglycaemia was the most severe, antibody titer was maximal. Similarly after three weeks of treatment, antibody titer and insulin-like effects of serum progressively decreased in vitro, concomitantly with an improvement of the glycaemic status.

At present, the mechanism responsible for occurrence of antibodies to insulin receptor remains a matter of speculation. Evidence for selective molecular interactions between insulin receptors and the major histocompatibility system antigens has been reported in human B lymphocytes [23]. Furthermore, polymorphism at the insulin receptor locus has been found [24]. It is thus conceivable that the insulin receptors of mother (the graft donor) and child are sufficiently different to lead to the generation of alloantibodies. Currently, we are investigating whether the antibodies present in P.S. serum are produced by the child's or the mother's lymphocytes. However, since the antibodies to insulin receptor appeared together with several autoantibodies, autoimmunity is the most likely hypothesis. Autoimmune manifestations have been described post bone marrow transplantation in patients with chronic graft versus host disease [26-29], but not uncommonly does autoimmunity appear to be independent of chronic GVHD in patients having received HLA incompatible bone marrow transplantation (unpublished observation). Note that P.S. had no clear manifestations of chronic GVHD. This autoimmunity process could also be related to the autoreactivity of engrafted T lymphocytes towards own HLA class II antigen potentially able to give non specific polyclonal help for B lymphocytes.

The results reported in this paper re-inforce the idea that antibodies to insulin receptor should be considered in the differential diagnosis of patients with idiopathic hypoglycaemia, particularly when autoimmune manifestations are present. The search for antibodies should comprise a comprehensive series of detection methods including immunoprecipitation of receptors, hormone binding assays in different systems, and biological assays. Indeed, some patients might develop antibodies to insulin receptor which are not directed against the insulin binding site but can, nevertheless, activate the receptor kinase and induce insulin-like effects as also described for some polyclonal or monoclonal antibodies $[10,30]$.

Acknowledgments. We thank Dr. A. Ullrich (Genentech, Inc., South San Francisco, Calif., USA) for the generous gift of the HIRc cell line [13]. We are greatly indebted to T. Grémeaux and G. Visciano for illustration work and expert technical assistance. We thank Drs. G. Ponzio, P. Freychet, B. Canivet for helpful discussion and Dr. J. Kubar for critical reading of the manuscript. This work was supported by grants from Institut National de la Santé et de la Recherche Médicale, France, University of Nice, France, GPA (Groupe des Populaires d'Assurances, France), Fondation pour la Recherche Médicale, France, and Bayer Pharma, France.

\section{References}

1. Kahn CR, Flier JS, Bar RS, Archer JA, Gorden P, Martin MM, Roth J (1976) The syndromes of insulin resistance and acanthosis nigricans: insulin-receptor disorders in man. $N$ Engl $J$ Med 294: 739-745

2. Taylor SI, Grunberger G, Marcus-Samuels B, Underhill LH, Dons RF, Ryan J, Roddam RF, Rupe CE, Gorden P (1982) Hypoglycemia associated with antibodies to the insulin receptor. N Engl J Med 307: 1422-1426

3. Elias D, Cohen IR, Shechter Y, Spirer Z, Golander A (1987) Antibodies to insulin receptor followed by anti-idiotype. Antibodies to insulin in child with hypoglycemia. Diabetes $36: 348-354$

4. De Pirro R, Roth RA, Rossetti L, Goldfine ID (1984) Characterization of the serum from a patient with insulin resistance and hypoglycemia. Evidence for multiple populations of insulin receptor antibodies with different receptor binding and insulinmimicking activities. Diabetes 33: 301-304

5. Braund WJ, Naylor BA, Williamson DH, Buley ID, Clark A, Chapel HM, Turner RC (1987) Autoimmunity to insulin receptor and hypoglycaemia in patient with Hodgkin's disease. Lancet I: $237-240$

6. Walters EG, Tavaré JM, Denton RM, Walters G (1987) Hypoglycaemia due to an insulin-receptor antibody in Hodgkin's disease. Lancet I: $241-243$

7. Griscelli C, Durandy A, Virelizier JL, Ballet JJ, Daguillard F (1978) Selective defect of precursor T cell associated with apparently normal B lymphocytes in severe combined immunodeficiency. J Pediatr 93: 404-411

8. Waldmann H, Polliak A, Hale G (1984) Elimination of graft versus host disease by in vitro depletion of alloreactive lymphocytes with monoclonal rat antihuman lymphocyte antibody (CAMPATH I). Lancet II: $483-486$

9. Fischer A, Durandy A, De Villartay JP, Vilmer E, Le Deist F, Gérota I, Griscelli C (1986) HLA haploidentical bone marrow transplantation for severe combined immunodeficiency using E rosette fractionation and cyclosporine A. Blood 67: 444-445

10. Ponzio G, Dolais-Kitabgi J, Louvard D, Gautier N, Rossi B (1987) Insulin and rabbit anti-insulin receptor antibodies stimulate additively the intrinsic receptor kinase activity. EMBO J 6 : 333-340

11. Freychet P, Roth J, Neville DM Jr (1971) Insulin receptors in the liver: specific binding of $\left[{ }^{125} I\right]$ Insulin to the plasma membrane and 
its relation to insulin bioactivity. Proc Natl Acad Sci USA 68: 1833-1837

12. Desbuquois B, Aurbach GD (1971) Use of polyethylene glycol to separate free and antibody-bound peptide hormones in radioimmunoassays. J Clin Endocrinol Metab 33: 732-738

13. McClain DA, Maegawa H, Lee J, Dull TJ, Ullrich A, Olefsky JM (1987) A mutant insulin receptor with defective tyrosine kinase displays no biological activity and does not undergo endocytosis. J Biol Chem 262: 14663-14671

14. Van Obberghen E, Kasuga M, Le Cam A, Hedo JA, Itin A, Harrison LC (1981) Biosynthetic labeling of insulin receptor: studies of subunits in cultured human IM-9 lymphocytes. Proc Natl Acad Sci USA 78: 1052-1056

15. Van Obberghen E, Rossi B, Kowalski A, Gazzano H, Ponzio G (1983) Receptor-mediated phosphorylation of the hepatic insulin receptor: evidence that the $\mathrm{Mr} 95000$ receptor subunit is its own kinase. Proc Natl Acad Sci USA 80: 945-949

16. Laemmli UK (1970) Cleavage of structural proteins during the assembly of the head of bacteriophage T4. Nature (London) 227: 680-685

17. Le Marchand-Brustel Y, Grémeaux T, Ballotti R, Van Obberghen $E$ (1985) Insulin receptor tyrosine kinase is defective in skeletal muscle of insulin-resistant obese mice. Nature (London) 315: 676-679

18. Le Marchand-Brustel Y, Gorden P, Flier JS, Kahn CR, Freychet $\mathbf{P}$ (1978) Antiinsulin receptor antibodies inhibit insulin binding and stimulate glucose metabolism in skeletal muscle. Diabetologia 14: 311-317

19. Snedecor GW, Cochran WG (1967) Statistical Methods, $6^{\text {th }}$ Edn. Iowa State University Press, Ames

20. Rosen OM (1987) After insulin binds. Science 237: 1452-1458

21. Gammeltoft S, Van Obberghen E (1986) Protein kinase activity of the insulin receptor. Biochem $\mathbf{J} 235: 1-11$

22. Ellis L, Clauser E, Morgan DO, Edery M, Roth RA, Rutter WJ (1986) Replacement of insulin receptor tyrosine residues 1162 and 1163 compromises insulin-stimulated kinase activity and uptake of 2-deoxyglucose. Cell 45: 721-732
23. Chou CK, Dull TJ, Russell DS, Gherzi R, Lebwohl D, Ullrich A, Rosen OM (1987) Human insulin receptors mutated at the ATPbinding site lack protein tyrosine kinase activity and fail to mediate postreceptor effects of insulin. J Biol Chem 262: 1842-1847

24. Samson M, Cousin JL, Fehlmann M (1986) Cross-linking of insulin receptors to MHC antigens in human B lymphocytes: evidence for selective molecular interactions. J Immunol 137: 2293-2298

25. Elbein SC, Corsetti L, Ullrich A, Permutt MA (1986) Multiple restriction fragment length polymorphisms at the insulin receptor locus: a bighly informative marker for linkage analysis. Proc Natl Acad Sci USA 83: 5223-5227

26. Gale RP (1985) Graft versus host disease. Immunol Rev 88: 193-215

27. Shulman HM, Sullivan KM, Weiden PL, McDonald GB, Striker GE, Sale GE, Hackman R, Tsoi MS, Storb R, Thomas ED (1980) Chronic GVH syndrome in man. A long term clinicopathologic study of 20 Seattle patients. Am J Med 69: 204-208

28. Sullivan KM, Deeg HJ, Sanders JE (1984) Late complication after bone marrow transplantation. Sernin Hematol 21: 53-59

29. De Villartay JP, Griscelli C, Fischer A (1986) Self tolerance to host and donor following HLA mismatched bone marrow transplantation. Eur J Immunol 16: 117-122

30. O'Brien RM, Soos MA, Siddle K (1987) Monoclonal antibodies to the insulin receptor stimulate the intrinsic tyrosine kinase activity by cross-linking receptor molecules. Embo J 6: 4003-4010

Received: 2 August 1988

and in revised form: 12 January 1989

Dr. N. Rochet

INSERM U145

Faculté de Médecine

Avenue de Valombrose

F-06034 Nice Cédex

France 